\title{
Incidence and Distribution of African Cassava Mosaic Virus in the Guinea Savannah Vegetation zone of Nigeria
}

\author{
Tolani Adegbite Okelola ${ }^{1,2, *}$, Shatu Wudiri Asala ${ }^{2}$, Akeem Abolade Oyerinde ${ }^{2}$, \\ Oladapo Oluwatobi Folarin ${ }^{1,2}$ \\ ${ }^{1}$ National Agricultural Seeds Council, Abuja, Nigeria \\ ${ }^{2}$ Department of Crop Protection, Faculty of Agriculture, University of Abuja, Abuja, Nigeria \\ Email address: \\ tolar26@yahoo.com (T. A. Okelola), shatuasala@yahoo.com (S. W. Asala), oyerindehyphae2002@gmail.com (A. A. Oyerinde), \\ oladapo.folarin@gmail.com (O. O. Folarin) \\ ${ }^{*}$ Corresponding author
}

\section{To cite this article:}

Tolani Adegbite Okelola, Shatu Wudiri Asala, Akeem Abolade Oyerinde, Oladapo Oluwatobi Folarin. Incidence and Distribution of African Cassava Mosaic Virus in the Guinea Savannah Vegetation zone of Nigeria. Journal of Plant Sciences. Vol. 9, No. 1, 2021 , pp. 1-8. doi: $10.11648 /$ j.jps.20210901.11

Received: October 31, 2020; Accepted: December 1, 2020; Published: January 12, 2021

\begin{abstract}
African Cassava Mosaic Virus (ACMV) is one of the major diseases affecting cassava production in Sub-Saharan Africa. A survey was conducted between August and September 2019 in the Federal Capital Territory (FCT), Niger and Benue states of the Guinea savannah vegetation zone of Nigeria, where cassava is predominantly cultivated, to assess the incidence and distribution of ACMV. Leaf samples collected from this survey were subjected to molecular indexing using Polymerase Chain Reaction (PCR). Further phylogenic analysis sequencing was done to determine the diversity among the isolates obtained from the study. A total of 81 farms were visited from where 2,025 symptomatic and asymptomatic leaf samples (25 leaf samples per farm) were collected randomly in quadrants of $5 \mathrm{~m} \times 5 \mathrm{~m}$. The surveyed fields were assessed for virus disease incidence and severity by visual observation. From the samples collected, FCT had the highest incidence (62\%) while Benue had the lowest (18\%). FCT also recorded the highest severity while Benue had the lowest. After molecular indexing using PCR, FCT recorded the highest incidence to ACMV (22.22\%), while no ACMV incidence was recorded in Benue state. The sequencing and phylogenic analysis reveals that there is a high diversity among the isolates obtained in the areas surveyed. This study indicates the presence of ACMV in the Guinea Savannah vegetation zone of Nigeria and has confirmed that cassava Mosaic Disease could be a threat to cassava production in the zone, therefore, the need for quick diagnosis.
\end{abstract}

Keywords: Virus, Survey, Cassava, Cassava Mosaic Disease, Polymerase Chain Reaction (PCR)

\section{Introduction}

Cassava (Manihot esculentus Crantz) is one of the leading staple foods in Nigeria. It is grown mainly for its enlarged starch-filled root which is used for human consumption, it is an energy-dense food and therefore, ranked high for its calorific value of $250 \times 103 \mathrm{cal} / \mathrm{ha} /$ day [1]. Cassava is a source of income and its production is vital to the economy of Nigeria as the country is the world's largest producer of the commodity; the crop is produced in 24 of the country's 36 states [2]. It is an important food security crop in Nigeria due to its increasing demand by the entire populace, as a result of the rapid population growth rate of the country [2]. Cassava can be processed into different intermediate finished products such as cassava flour, starch, cassava chips and garri. Due to its high amylose and starch content it is used to produce high fructose syrup and glucose for beverage and in the pharmaceutical industries [3].

There are many factors that serve as constraints to cassava production this includes; diseases, insects, soil, weeds and agronomical factors [2]. Insects such as cassava mealybug, cassava green mite and whitefly affect cassava production through introduction of viral diseases [4]. Cassava mosaic disease (CMD) is another major constraint, to cassava production in Africa and is caused by eight distinct members of the family Geminiviridae, commonly referred to as Cassava mosaic Geminiviruses (CMGs) $[5,6]$. CMD can results in 
stunting and severe reduction of about $20 \%$ to $95 \%$ in the yield of the desired tuberous cassava root and can cause production threat to cassava which feeds over 200 million people in subSaharan Africa. [7]. CMD has been reported to occur at varying levels of incidence throughout the cassava belt of Africa [8]. For many years African cassava mosaic virus (ACMV) was confirmed as the causal agent of CMD, it remained the only known causal agent of CMD in Nigeria until the 1990s when East African cassava mosaic Cameroon virus (EACMCV) and several variants of the EACMV were diagnosed as additional causative agents $[9,10]$.

Cassava plants that were infected with CMGs express a range of symptoms depending on various factors such as the virus strain or species, environmental conditions and the susceptibility of the cassava host [11]. ACMV infected plants are stunted with conspicuous foliar symptoms such as mosaic and chlorosis interfering with the photosynthetic ability of the plant to produce food for storage in the roots, thus, infected plants yield is greatly reduced [12].

The lack of adequate information on ACMV in the Guinea Savannah and the need to understand the spread of cassava mosaic disease across the zone necessitated this study to be carried out within the Guinea savannah vegetation zone of Nigeria, with the objective to study the incidence and distribution of ACMV in the guinea savannah vegetation zone of Nigeria.

\section{Materials and Methods}

A survey was conducted between August and September 2019 covering all the major cassava-growing Local Government Areas (LGAs) of Kuje, Bwari and Kwali in FCT; Bida, Shiroro and Agaie in Niger state; and Markurdi, Gboko and Guma in Benue state of the guinea savannah ecological zone of Nigeria. At each survey site, geo-reference points were taken using Global Positioning System equipment (eTrex, Gramin, 12 Channels GPS Corporation, Taiwan). A total of 81 farmers were interviewed using a questionnaire that included socio-economic characteristics of farmers such as: occupation of farmer, age, gender, educational qualifications, source of seed, varieties of cassava grown and most preferred cassava variety. Sampling was carried out within the 3 states where cassava is predominantly cultivated in the guinea savannah vegetation zone. Within each state, 27 farmers were interacted with, and samples drawn from young fields of between 3-6 months old.

Samples of leaves were collected in quadrants of $5 \mathrm{~m}$ by $5 \mathrm{~m}$ size, and leaf samples were collected from 25 plants. 9 fields were assessed per LGA or Area Council with a total of 27 fields per state. 675 samples were collected from each state, bringing the total number of leaf samples collected to 2025 from 81 farms. Leaf samples were collected from symptomatic plants showing symptoms such as chlorosis, mosaic and leaf distortion, as well as from asymptomatic plants. Leaves were collected from the top, middle and lower portion of each plant. The leaves were carefully placed in sample bottles which contain Calcium Chloride $\left(\mathrm{CaCl}_{2}\right)$, well labeled and stored [13]. The surveyed fields were assessed for virus Disease Incidence (DI), by visual observation through random selection of 5 plants per quadrant, after which 5 symptomatic and asymptomatic leaf samples were collected per quadrant. The total number of plants that exhibited virus-like symptoms were expressed as percentage of total number of plants (25) sampled [14]. The severity of disease on symptomatic plant was carried out by visual examination and was scored using 1 to 5 rating scale as described by [15] where $1=$ no symptoms, $2=$ slight chlorosis (symptoms on $1-25 \%$ of the leaves), $3=$ mild chlorosis, mild distortions at bases of most leaves while the remaining parts of the leaves and leaflets appear green and healthy (symptoms on $26-50 \%$ of the leaves), $4=$ pronounced mosaic pattern on most leaves, narrowing and distortion of the lower one-third of the leaflets (symptoms on $51-75 \%$ of the leaves) and $5=$ severe mosaic distortion of two-thirds of most leaves and a general reduction of leaf size and stunting of shoots (symptoms on $76-100 \%$ of the leaves).

\subsection{Extraction of Total Nucleic Acid}

Total nucleic acid of the cassava leaf samples was extracted using modified Cetryl trimethyl ammonium bromide (CTAB) protocol (0.1 M Trizma base, $0.02 \mathrm{M}$ ethylene-diamine tetra acetic acid (EDTA), $1.4 \mathrm{M}$ of $\mathrm{NaCl}$ and 2\% CTAB powder, $\mathrm{pH} 8.0$ ) [16].

\subsection{Indexing for ACMV Using PCR}

The assay used is a multiplex primer sequence set of OJARep F: 5'- CRT CAA TGA CGT TGT ACCA -3' ACMVRepR: CAG CGG MAG TAA GTC MGA EACMV- Rep R: GGT TTG CAG AGA ACTA CATC it has expected band size of $650 \mathrm{bp}$ and $358 \mathrm{bp}$. A total of $10.5 \mu 1$ reaction mixture containing $2.5 \mu \mathrm{l}$ of $5 \mathrm{x}$ green buffer (Promega, USA), $0.75 \mu \mathrm{l}$ of $25 \mathrm{mM} \mathrm{MgCl}, 0.25 \mu \mathrm{l}$ of $10 \mathrm{mM}$ of deoxyribonucleic acids (dNTPs), $0.25 \mu \mathrm{l}$ each of $10 \mathrm{mM}$ solution of forward and reverse primers (ACMV rep and EACMV rep of OJA MIX,), $0.06 \mu \mathrm{I}$ Taq $5 \mathrm{u} / \mu \mathrm{I}$ DNA polymerase (Biolab, USA), and made up with $6.69 \mu \mathrm{l}$ of sterile distilled water to a total volume of $10.5 \mu 1$. This master mix was carefully pipetted into microtubes (Thermo-scientific, United Kingdom), and $2 \mu \mathrm{l}$ of nucleic acid template (dilution 1:50) was added upon constitution of reaction mixture making a total of $12.5 \mu \mathrm{l}$ [10].

The PCR products were resolved on $2 \%$ agarose gel stained with GR green $(5 \mu 1 / 100 \mathrm{ml})$ and run in electrophoretic tank (VWR stock code: E1020-20-VWR, Max current: $250 \mathrm{Ma}$, Max volt: 500VDC, UK) containing TAE buffer $\mathrm{pH} 8.0$ at 120 volts for 40 minutes. 100bp DNA Ladder (Thermo Scientific, GeneRuler 100bp Plus, California, USA) was used as standard against which amplicons sizes were calibrated. The gel result was viewed under UV transilluminator (EZ imager, Bio-Rad, Inc, USA). The presence of amplicons corresponding to bands size of partial ACMV coat protein is scored per genotype visually based on viewed gel. 


\subsection{Distribution of ACMV}

The Longitude and Latitude coordinates of the samples surveyed were superimposed on the agro-ecological map of Nigeria using computer software (ArcGis version 9.1) at the Department of Geography and Environmental University of Abuja. This was done to relate the distribution of ACMV across all the farms visited within the Guinea savannah agroecological zone.

\section{Results}

\subsection{Survey of ACMV}

There were different virus symptoms expressed on all the

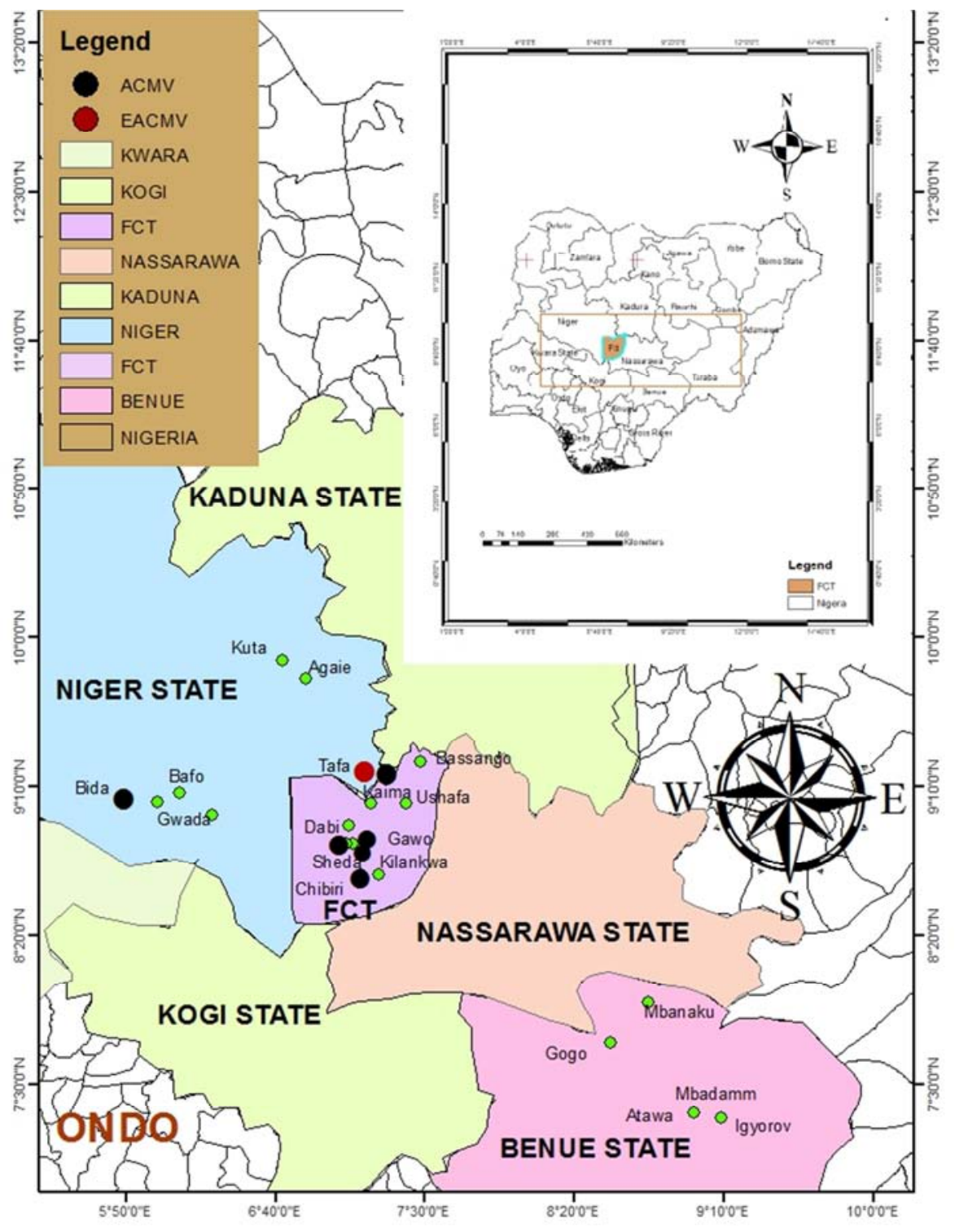

Figure 1. Distribution of ACMV in the Guinea savannah Vegetation zone of Nigeria.

\subsection{Incidence and Severity of ACMV in Guinea Savannah Zone of Nigeria}

The incidence and severity values for ACMV according to leaf samples collected, chlorotic mosaic was the most common symptom observed followed by mottling, leaf curling and distortion. The collected samples also had a mixture of different symptoms such as chlorotic mosaic and distortion; occurring on a single plant and this was recorded mostly in FCT. The incidence observed in Niger was $20 \%$ while Benue was $18 \%$. FCT had a higher incidence of $62 \%$. Symptom severity was mild in all the farms visited in Markurdi, Gboko and Guma LGAs of Benue State, (Figure 1). In Bida, Shiroro and Lavun LGAs of Niger State, symptom severity was either mild or moderately severe in most fields visited. Symptoms observed in Kuta area in Bida LGA were severe in all the three farms visited. 
Gawo respectively. The lowest incidence of $6.67 \%$ was observed in Kuma, which was statistically similar to Nalegh, Chukuku, Ushafa, Batagi, Gwada, Zari and Adatu. The highest severity of $(13.33 \%)$ was recorded in Nalegh and Gwada while Kilankwa had the lowest (5.32\%), closely followed by $6.67 \%$ in Sheda. In Niger state, Bida and Tafa recorded an incidence of $100 \%$ while Benue state did not record any incidence in all the fields visited.

Table 1. Mean incidence and severity of ACMV in the Guinea Savannah Vegetation Zone of Nigeria.

\begin{tabular}{|c|c|c|c|c|}
\hline STATE & LGA & LOCATION & $\begin{array}{l}\text { FIELD } \\
\text { INCIDENCE }\end{array}$ & $\begin{array}{l}\text { DISEASE } \\
\text { SEVERITY }\end{array}$ \\
\hline \multirow[t]{9}{*}{ FCT } & \multirow[t]{3}{*}{ Kwali } & DABI & $16.00^{\mathrm{de}}$ & $12.00^{\mathrm{b}}$ \\
\hline & & KILANKWA & $25.33^{\mathrm{de}}$ & $5.32^{\mathrm{g}}$ \\
\hline & & SHEDA & $60.00^{\mathrm{ab}}$ & $6.67^{f}$ \\
\hline & \multirow[t]{3}{*}{ Kuje } & CHUKUKU & $10.67^{\mathrm{e}}$ & $7.99^{d}$ \\
\hline & & CHIBIRI & $21.33^{\mathrm{de}}$ & $8.00^{d}$ \\
\hline & & GAWO & $54.66^{\mathrm{bc}}$ & $8.00^{d}$ \\
\hline & \multirow[t]{3}{*}{ Bwari } & USHAFA & $10.67^{\mathrm{e}}$ & $7.93^{d}$ \\
\hline & & BASANGO & $21.33^{\mathrm{de}}$ & $10.66^{\mathrm{c}}$ \\
\hline & & KUMA & $6.67^{\mathrm{e}}$ & $7.99^{d}$ \\
\hline \multirow[t]{6}{*}{ NIGER } & \multirow[t]{3}{*}{ Bida } & BIDA & $78.66^{\mathrm{a}}$ & $10.66^{\mathrm{c}}$ \\
\hline & & BANGIE & $26.67^{\mathrm{de}}$ & $8.00^{\mathrm{d}}$ \\
\hline & & TATA & $38.67^{\mathrm{cd}}$ & $7.99^{d}$ \\
\hline & \multirow[t]{3}{*}{ Shiroro } & KUTA & $18.67^{\mathrm{de}}$ & $8.00 \mathrm{~d}$ \\
\hline & & GWADA & $13.33^{\mathrm{e}}$ & $13.33^{\mathrm{a}}$ \\
\hline & & ZARI & $12.00^{\mathrm{e}}$ & $7.99^{d}$ \\
\hline \multirow[t]{12}{*}{ BENUE } & \multirow[t]{6}{*}{ Agaie } & AGAIE & $16.00^{\mathrm{de}}$ & $7.99^{d}$ \\
\hline & & BATAGI & $13.33^{\mathrm{e}}$ & $7.99^{d}$ \\
\hline & & BAFO & $17.33^{\mathrm{de}}$ & $8.00^{d}$ \\
\hline & & ADATU & $14.67^{\mathrm{e}}$ & $8.00^{d}$ \\
\hline & & KACHI & $17.33^{\mathrm{de}}$ & $8.00^{\mathrm{d}}$ \\
\hline & & IKAN & $22.67^{\text {de }}$ & $10.66^{\mathrm{c}}$ \\
\hline & \multirow[t]{6}{*}{ Gboko } & MBANAKU & $21.33^{\mathrm{de}}$ & $7.99^{d}$ \\
\hline & & MBANDAMM & $17.33^{\mathrm{de}}$ & $7.99^{d}$ \\
\hline & & IGYOROV & $20.00^{\text {de }}$ & $8.00^{d}$ \\
\hline & & ATAWA & $24.0^{\mathrm{de}}$ & $8.00^{d}$ \\
\hline & & GOGO & $26.67^{\mathrm{de}}$ & $8.00^{\mathrm{d}}$ \\
\hline & & NALEGH & $14.67^{\mathrm{e}}$ & $13.33^{\mathrm{a}}$ \\
\hline
\end{tabular}

Means followed by the same alphabet along the column are not different from another at $5 \%$ probability level $\mathrm{P} \leq 0.05$

\subsection{ACMV in Cassava Leaves Using PCR}

2025 samples were bulked into 81 samples based on the number of fields visited. The disease incidence and severity varied within the locations and among different varieties of cassava being cultivated. Of the 81 bulked samples tested, $22.22 \%$ of leaf samples tested positive to ACMV in FCT while $14.81 \%$ tested positive in Niger State. On the other hand, no sample tested positive to ACMV in Benue ( $0 \%$ ) (Table 2).

Table 2. Incidence of ACMV infecting cassava (Manihot esculenta) in FCT, Niger and Benue states of the Guinea Savannah Vegetation Zone of Nigeria.

\begin{tabular}{llll}
\hline ACMV & & & \\
\hline State & Ns & Np & \% \\
\hline FCT & 27 & 6 & 22.22 \\
NIGER & 27 & 4 & 14.81 \\
BENUE & 27 & 0 & 0 \\
TOTAL & 81 & 10 & 12.34 \\
\hline
\end{tabular}

Ns-Number of leaves sampled; Np-Number of positive samples; ACMVAfrican Cassava Mosaic Virus

\subsection{Distribution and Incidence of ACMV}

Table 3 shows the mean separation of the PCR result which indicated that ACMV was detected from the 27 farms surveyed in FCT. In Kwali Area Council Sheda and Kilankwa recorded $22.22 \%$ and $11.11 \%$ positive samples respectively while Dabi had no positive sample. Kuje Area Council had $11.11 \%$ and $1 \%$ positive samples in Chibiri and Gawo respectively while Chukuku had no positive sample. In Bwari Area Council, the samples did not test positive to ACMV. Statistical analysis of all the parameters and the PCR result indicated a significant difference between the farmers preferred varieties and ACMV incidence. The result also indicated that cassava varieties of $98 / 0505$, NR 8212 and TME 419 were predominantly propagated in FCT.

In Niger State, Bida LGA had $11.11 \%$ and $0.66 \%$ positive samples in Tafa and Bangie respectively while no sample tested positive in Bida. No sample tested positive in Shiroro and Agaie LGAs (Table 4). Statistically, the PCR result and other parameters like the varieties used, showed a significant difference with the presence of ACMV and the farmer preferred cassava varieties of $98 \backslash 0505$ and NR 8212 which were the two major varieties produced by the farmers in Niger while in Benue State, all samples collected from the field did not test positive to ACMV (Table 5). The preferred varieties of cassava grown in Benue state were TME 419 and BRANADA.

Table 3. Mean distribution and Incidence of ACMV infecting different cassava varieties in FCT.

\begin{tabular}{|c|c|c|c|c|c|c|c|}
\hline \multirow{2}{*}{ LGA } & \multirow{2}{*}{ LOCATION } & \multirow{2}{*}{\multicolumn{2}{|c|}{ VIRUS PRESENT }} & \multicolumn{4}{|l|}{ VARIETY } \\
\hline & & & & BRANADA & TME 419 & 98/0505 & NR 8212 \\
\hline \multirow[t]{3}{*}{ KWALI } & DABI & ACMV & $0.00^{\mathrm{c}}$ & $0.00^{\mathrm{c}}$ & 1.00 & $0.00^{\mathrm{c}}$ & $0.00^{\mathrm{c}}$ \\
\hline & KILANKWA & ACMV & $11.11^{\mathrm{bc}}$ & $0.67^{b}$ & $0.33^{\mathrm{bc}}$ & $0.33^{\mathrm{bc}}$ & $0.33^{\mathrm{ab}}$ \\
\hline & SHEDA & ACMV & 22.22 & $0.33^{\mathrm{c}}$ & $0.33^{\mathrm{bc}}$ & $0.67^{\mathrm{ab}}$ & $0.67^{\mathrm{ab}}$ \\
\hline \multirow[t]{3}{*}{ KUJE } & CHUKUKU & ACMV & $0.00^{\mathrm{c}}$ & $0.00^{\mathrm{d}}$ & $1.00^{\mathrm{a}}$ & $0.00^{\mathrm{c}}$ & $0.00^{\mathrm{c}}$ \\
\hline & CHIBIRI & ACMV & $11.11^{\mathrm{bc}}$ & $0.00^{\mathrm{d}}$ & $6.67^{\mathrm{ab}}$ & $0.33^{\mathrm{bc}}$ & $0.33^{\mathrm{bc}}$ \\
\hline & GAWO & ACMV & $1.00^{\mathrm{a}}$ & $0.00^{\mathrm{d}}$ & $0.00^{\mathrm{c}}$ & $1.00^{\mathrm{a}}$ & $1.00^{\mathrm{a}}$ \\
\hline \multirow{2}{*}{ BWARI } & BASANGO & ACMV & 0.00 & $0.00^{\mathrm{d}}$ & $1.00^{\mathrm{a}}$ & $0.00^{\mathrm{c}}$ & $0.00^{\mathrm{c}}$ \\
\hline & KAIMA & ACMV & $0.00^{\mathrm{c}}$ & $0.00^{\mathrm{d}}$ & $1.00^{\mathrm{a}}$ & $0.00^{\mathrm{c}}$ & $0.00^{\mathrm{c}}$ \\
\hline
\end{tabular}

Means in the same column with different alphabets are significantly different at $\mathrm{P} \leq 0.05$ 
Table 4. Mean distribution and Incidence of ACMV infecting different cassava varieties in Niger state.

\begin{tabular}{|c|c|c|c|c|c|c|c|}
\hline \multirow{2}{*}{ LGA } & \multirow{2}{*}{ LOCATION } & \multirow{2}{*}{\multicolumn{2}{|c|}{ VIRUS PRESENT }} & \multicolumn{4}{|l|}{ VARIETIES } \\
\hline & & & & BRANADA & TME419 & $98 / 0505$ & NR 8212 \\
\hline \multirow[t]{3}{*}{$\overline{B I D A}$} & BIDA & ACMV & 0.00 & $0.00^{\mathrm{d}}$ & $0.00^{\mathrm{c}}$ & $1.00^{\mathrm{a}}$ & $0.00^{\mathrm{c}}$ \\
\hline & BANGIE & ACMV & $0.66^{\mathrm{bc}}$ & $0.00^{\mathrm{d}}$ & $0.00^{\mathrm{c}}$ & $0.33^{\mathrm{bc}}$ & $1.00^{\mathrm{a}}$ \\
\hline & TAFA & ACMV & $11.11^{\mathrm{bc}}$ & $0.00^{\mathrm{d}}$ & $0.00^{\mathrm{c}}$ & $1.00^{\mathrm{a}}$ & $1.00^{\mathrm{a}}$ \\
\hline \multirow[t]{3}{*}{ SHIRORO } & KUTA & ACMV & $0.00^{\mathrm{c}}$ & $0.00^{\mathrm{d}}$ & $1.00^{\mathrm{a}}$ & $0.33^{\mathrm{bc}}$ & $0.67^{\mathrm{ab}}$ \\
\hline & GWADA & ACMV & $0.00^{\mathrm{c}}$ & $0.00^{\mathrm{d}}$ & $1.00^{\mathrm{a}}$ & $0.00^{\mathrm{c}}$ & $0.00^{\mathrm{c}}$ \\
\hline & ZARI & ACMV & $0.00^{\mathrm{c}}$ & $0.00^{\mathrm{d}}$ & $1.00^{\mathrm{a}}$ & $0.00^{\mathrm{c}}$ & $0.00^{\mathrm{c}}$ \\
\hline \multirow[t]{3}{*}{ AGAIE } & AGAIE & ACMV & $0.00^{\mathrm{c}}$ & $1.00^{\mathrm{a}}$ & $0.33^{\mathrm{bc}}$ & $0.00^{\mathrm{c}}$ & $0.00^{\mathrm{c}}$ \\
\hline & BATAGI & ACMV & $0.00^{\mathrm{c}}$ & $1.00^{\mathrm{a}}$ & $1.00^{\mathrm{a}}$ & $0.00^{\mathrm{c}}$ & $0.00^{\mathrm{c}}$ \\
\hline & BAFO & ACMV & $0.00^{\mathrm{c}}$ & $1.00^{\mathrm{a}}$ & $0.00^{\mathrm{c}}$ & $0.00^{\mathrm{c}}$ & $0.00^{\mathrm{c}}$ \\
\hline
\end{tabular}

Means in the same column with different alphabets are significantly different at $P \leq 0.05$

Table 5. Mean distribution and Incidence of ACMV infecting different cassava varieties in Benue state.

\begin{tabular}{|c|c|c|c|c|c|c|c|}
\hline \multirow{2}{*}{$\begin{array}{l}\text { LGA } \\
\text { MAKURDI }\end{array}$} & \multirow{2}{*}{$\begin{array}{l}\text { LOCATION } \\
\text { ADAKA }\end{array}$} & \multicolumn{2}{|c|}{ VIRUS PRESENT } & \multirow{2}{*}{$\begin{array}{l}\text { BRANADA } \\
1.00^{\mathrm{a}}\end{array}$} & \multirow{2}{*}{$\begin{array}{l}\text { TME } 419 \\
1.00^{\mathrm{a}}\end{array}$} & \multirow{2}{*}{$\begin{array}{l}\mathbf{9 8 / 0 5 0 5} \\
0.00^{\mathrm{c}}\end{array}$} & \multirow{2}{*}{$\begin{array}{l}\text { NR-8212 } \\
0.00^{\mathrm{c}}\end{array}$} \\
\hline & & ACMV & $0.00^{\mathrm{C}}$ & & & & \\
\hline & KACHI & ACMV & $0.00^{\mathrm{C}}$ & $1.00^{\mathrm{a}}$ & $1.00^{\mathrm{a}}$ & $0.00^{\mathrm{c}}$ & $0.00^{\mathrm{c}}$ \\
\hline & IKAN & ACMV & $0.00^{\mathrm{C}}$ & $1.00^{\mathrm{a}}$ & $1.00^{\mathrm{a}}$ & $0.00^{\mathrm{c}}$ & $0.00^{\mathrm{c}}$ \\
\hline \multirow[t]{3}{*}{ GBOKO } & MBANAKU & ACMV & $0.00^{\mathrm{C}}$ & $1.00^{\mathrm{a}}$ & $1.00^{\mathrm{a}}$ & $0.00^{\mathrm{c}}$ & $0.00^{c}$ \\
\hline & MBADAMM & ACMV & $0.00^{\mathrm{C}}$ & $1.00^{\mathrm{a}}$ & $0.00^{\mathrm{c}}$ & $0.00^{\mathrm{c}}$ & $0.00^{\mathrm{c}}$ \\
\hline & IGYOROV & ACMV & $0.00^{\mathrm{C}}$ & $1.00^{\mathrm{a}}$ & $0.00^{\mathrm{c}}$ & $0.00^{\mathrm{c}}$ & $0.00^{\mathrm{c}}$ \\
\hline \multirow[t]{3}{*}{ GUMA } & ATAWA & ACMV & $0.00^{\mathrm{C}}$ & $1.00^{\mathrm{a}}$ & $0.00^{\mathrm{c}}$ & $0.00^{\mathrm{c}}$ & $0.00^{\mathrm{c}}$ \\
\hline & GOGO & ACMV & $0.00^{\mathrm{C}}$ & $1.00^{\mathrm{a}}$ & $0.00^{\mathrm{c}}$ & $0.00^{\mathrm{c}}$ & $0.00^{\mathrm{c}}$ \\
\hline & NALEGH & ACMV & $0.00^{\mathrm{C}}$ & $1.00^{\mathrm{a}}$ & $0.00^{\mathrm{c}}$ & $0.00^{\mathrm{c}}$ & $0.00^{\mathrm{c}}$ \\
\hline
\end{tabular}

Means in the same column with different alphabets are significantly different at $\mathrm{P} \leq 0.05$
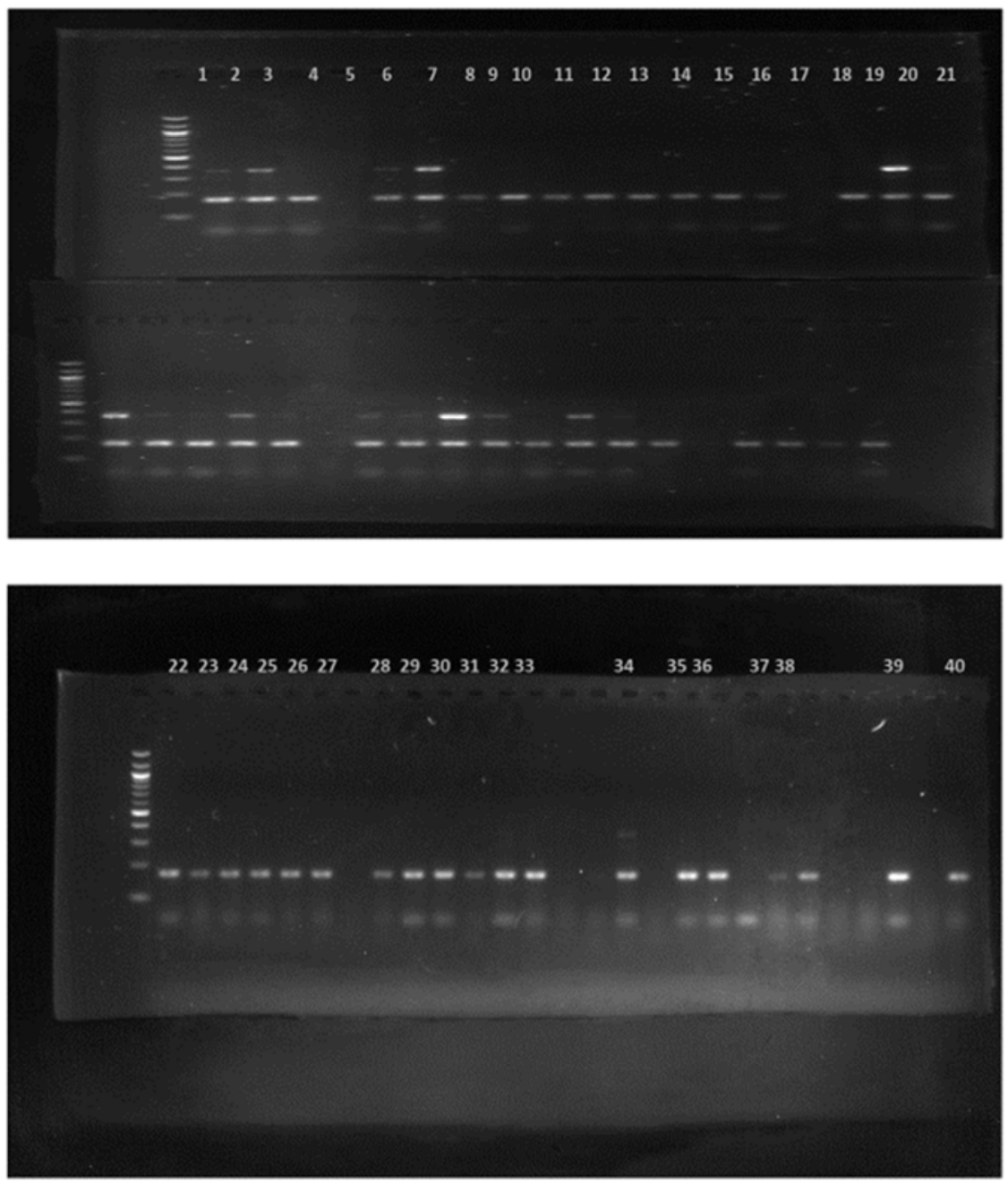

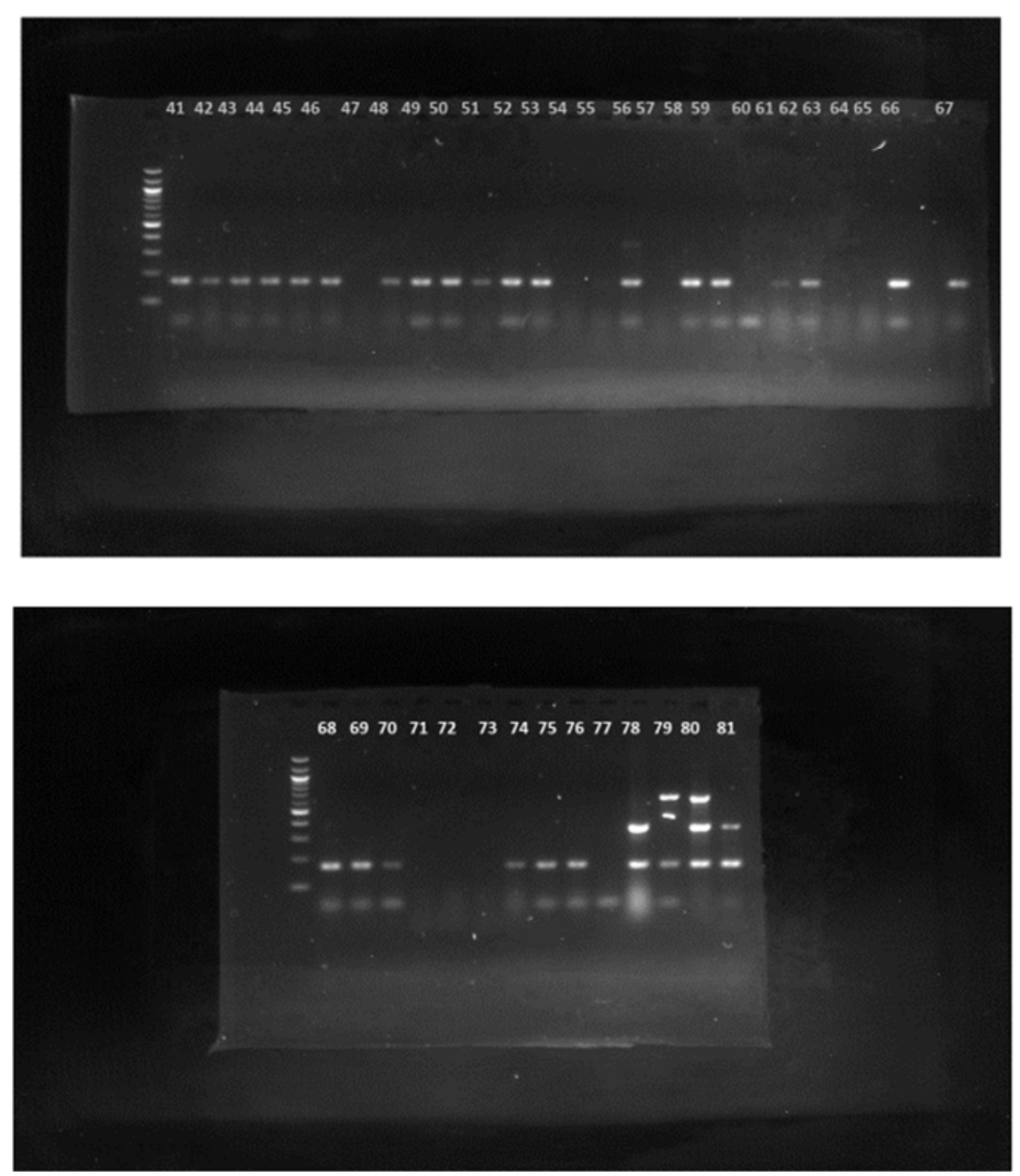

Figure 2. Agarose gel electrophoresis picture of resolved amplified PCR products of (a) indexing ACMV partial coat protein gene (600BP and) in source 81 cassava test samples-: 1-81, M-100bp DNA ladder, H-Healthy control, and D-Disease control.

\subsection{Diversity of ACMV Isolates by Phylogenetic Analysis}

The analyzed nucleotide sequences of ACMV isolates obtained from infected cassava leaf samples from FCT and Niger state shows different variability. Result from the BLAST analysis shows counterpart isolates from other locations (Figure 3).

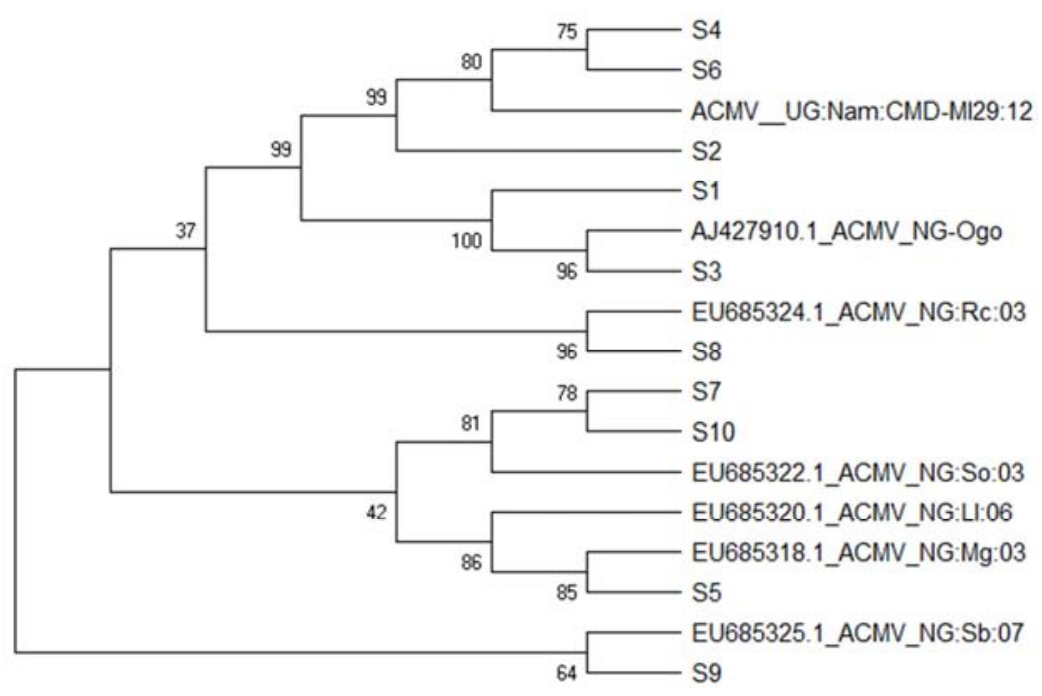

Figure 3. Consensus phylogenetic tree (1000 bootstraps) constructed by maximum-likelihood method. This was inferred based on full-length coat protein sequence of ACMV isolates from cassava using MEGA6® software. Percent bootstrap values are indicating at the branch nodes. 
The result showed that sample S1 (F8 Sheda) showed 100\% evolutionary relationship with sample S3 (F9 Sheda) which showed $96 \%$ relatability with the Nigerian isolate of ACMV with strain ID ACMV_NG-Ogo. Sample S2 (F16 Gawo) showed $99 \%$ relatability with samples S4 (F17 Gawo) and Sample S6 (F18 Gawo ) both having 75\% relatability and showed evolutionary relationships with Ugandan strains of ACMV having strain ID of ACMV_UG: Nam:CMDM129:12.

Samples S7 (F28 Bida), S5 (F30 Bida) and S10 (F29 Bida) have $78 \%$ relatability with each other and showed $81 \%$ evolutionary relationship with ACMV Nigerian strains, NG: So:03 and ACMV_NGL1:06. While sample S8 (F5 Kilankwa) showed 96\% relatability with ACMV Nigerian strain Rc:03. Furthermore, sample S9 (F15 Chibiri) showed 64\% relatability with ACMV Nigerian strain NG: Sb:07.

This result indicates that there is distinct diversity and variability in ACMV isolates identified in the surveyed areas and also, the nucleotide sequences obtained from source cassava leaves sequences have above 98\% sequence similarities with matches observed in the evolutionary relationship sequences of West Africa and East Africa origins as shown on the phylogenetic tree.

\section{Discussion}

This study provides information on the incidence and distribution of ACMV infecting cassava in FCT, Niger, and Benue states within the Guinea Savannah vegetation zone of Nigeria. Low incidence in Benue and Niger states was recorded in this study, and this could be attributed to the use of resistance varieties by most of the farmers in these areas. The highest incidence of ACMV recorded in FCT could have been introduced through the stem cuttings, because most of the cassava varieties used by majority of the farmers visited were saved stem cuttings. Farmer's continuous use of same stem stalk without achieving their expected harvest yield and not adopting other new resistant cultivars may further lead to the spread of Cassava Mosaic Geminiviruses [17]. Ogbe [7] in his research on the status of cassava Begomoviruses in Nigeria observed mild to moderately severe severity symptoms of CMD in FCT, Niger and Benue States. Most cassava farms surveyed in FCT were symptomatic and they were either moderately severe or severe mosaic infection in most farms. Eni [11] observed zero incidence of ACMV in samples collected from three out of the four selected states of the southern part of Nigeria which she attributed to the use of resistance varieties by the farmers in the region. ACMV was detected in other plant parts and was not restricted to the cassava leaves, therefore, becoming a great source of concern in the Guinea Savannah zone of Nigeria [6]. Samples collected from Niger and Benue states indicated low incidence where majority of the farmers propagates cassava stems that are resistance to CMD.

The low incidence observed in this study is similar to the research done by Eni [19]. However, this study differs from some reports from previous surveys in some parts of Nigeria where high incidence of CMD was reported [18]. The general low incidence recorded in this research may also be linked to good agronomic practices.

BRANADA is majorly propagated in Benue and majorly supplied by the Benue State Agricultural Development Programme (ADP) as part of its contribution to the eradication of CMD. According to the farmers, it is also preferred because of its sweetness and high yield potential. No positive sample to ACMV was recorded in Benue State. This may be due to the adoption of resistant varieties (TME 419 and BANADA) by farmers in Benue.

\section{Conclusion}

ACMV was found infecting cassava leaves collected from farms in the Guinea Savannah ecological zone of Nigeria. The phylogenic analysis sequencing result reveals that there is a high diversity among the isolates obtained in the study area. This could have probably been due to bio-geographical diversification and the vast distribution of the virus worldwide.

More awareness should be created to clear the myth of using saved stems by farmers; they should be enlightened on the use of improved planting materials. Also, government should provide on-farm easy to use diagnostic equipment to farmers through ADPs, so they can make quick decisions for management and control in case of infections.

\section{Conflict of Interest}

The authors have not declared any conflict of interests.

\section{Acknowledgements}

The authors wish to sincerely thank the Management of the National Agricultural Seeds Council (NASC), Abuja, Nigeria and the International Institute for Tropical Agriculture (IITA), Ibadan, Nigeria for their technical support during my bench work for this research at the institute.

\section{References}

[1] Jisha, S., Padmaja G. and Sajeev, M. S. (2010). Nutritional and textural studies on dietary fiber-enriched muffins and biscuits from cassava-based composite flours. Journal of Food Quality 33: 79-99.

[2] Food and Agriculture Organization (2014). Crop Production data 2013, FAOSTAT. Rome, Italy. Available at: http://www.fao.org.

[3] Afoakwa, E. O., Asiedu, C., Budu, A. S., Chiwona-Karltun, L., Nyirendah, D. B. (2012). Chemical composition and cyanogenic potential of traditional and high yielding CMD resistant cassava (Manihot esculenta Crantz) varieties. International Food Research Journal 19 (1): 175-181. 
[4] Fauquet, C. M., Maxwell, D. P., Gronenborn, B. \& Stanley, J. (2008). Revised proposal for naming of geminiviruses. Archives of Virology 145/8, 1744-1761.

[5] Fauquet, C. M. \& Stanley, J. (2003). Geminivirus classification and nomenclanture: progress and problems. Annals of Applied Biology 142, 165-189.

[6] Thresh J. M, Cooter RJ (2005). Strategies for controlling cassava mosaic virus disease in Africa. Plant Pathol. 54:587614. infections with African cassava mosaic virus in Nigeria. Plant Dis. 87: 229-232.

[7] Ogbe F. O, Atiri GI, Dixon A. G. O, Thottappilly G (2003). Cassava mosaic disease and its causal agents: the Nigerian situation In: Proceedings of the First International Conference on Plant Virology in Sub-Saharan Africa (4-8 June 2001, Ibadan, Nigeria), IITA, Ibadan, Nigeria. pp. 411-422.

[8] Alabi, O. J., Kumar, P. L., and Naidu, R. A. (2011). Cassava mosaic disease: A curse to food security in Sub-Saharan Africa. Online. APSnet Features. doi:10.1094/APSnetFeature-20110701 .

[9] Ogbe F. O, Dixon A. G. O, Hughes J, Alabi O. J, Okechukwu $R$ (2006). Status of cassava begomoviruses and their new natural hosts in Nigeria. Plant Dis. 90: 548-553.

[10] Alabi O. J, Kumar P. L, Rayapati A. N. (2008). Multiplex PCR for the detection of African cassava mosaic virus and East African cassava mosaic Cameroon virus in cassava. J. Virol. Methods 154: 111-120.

[11] Eni A. O., Fasasi D. K. (2013). Molecular detection of two cassava Begomoviruses in some parts of Southern Nigeria. African Journal of Agricultural Research. Vol. 8 (16), pp. 1350 -1353 .

[12] Mulenga, R. M., Legg, J. P., Ndunguru, J., Chikoti, P. C., Miano, D. W., Mutitu, W. E., and Alabi, O. J. (2016). Survey, molecular detection, and char-acterization of geminiviruses associated with cassava mosaic disease in Zambia. Plant Dis. 100: 1379-1387.

[13] Asala, Shatu Wudiri \& Alegbejo, Matthew \& Kashina, B. \& Banwo, Olalekan \& Robert, Asiedu \& Kumar, Lava. (2012). Distribution and incidence of viruses infecting yam (Dioscorea spp.) in Nigeria. Glob. J. Biosci. Biotechnol. Lett.. 1. 163-167.

[14] Odedara, O. O., Hughes, J. Ode bode, A. C., Odu, B. O. (2008). Multiple Virus infection of lablab in Nigeria. Journal of General Pathology. 74: 322-325.

[15] Eni A. O., Hughes J. D and Rey M. E. C (2008). Survey of the incidence and distribution of five viruses infecting yam in major yam producing zones of Nigeria. Annals of applied Biology 153: 223-232.

[16] Abarshi, M. M., Mohammed, I. U., Wasswa, P., Hillocks, R. J., Holt, J., Legg, J. P. Seal, S. E.; Maruthi, M. N. (2010). Optimization of diagnostic RT-PCR protocols and sampling procedures for the reliable and cost-effective detection of Cassava brown streak virus. Journal of Virological Methods, $163,353-359$.

[17] Asare, P. A., Galyuon, I. K. A., Asare-Bediako, E., Sarfo, J. K., Tetteh, J. P. (2014). Phenotypic and molecular screening of cassava (Manihot esculentum Crantz) genotypes for resistance to cassava mosaic disease. Journal of General and Molecular Virology, 6 (2), 6-18.

[18] Alabi, O. J., Mulenga, R. M., Legg, J. P. (2015). Cassava mosaic. In: Virus diseases of tropical and subtropical crops, [ed. by Tennant, P., Fermin, G.]. Wallingford, UK: CAB International. 56-72.

[19] Eni, A. O., Efekemo, O. P., Soluade, M. G., Popoola, S. I., \& Atayero, A. A. (2018). Incidence of cassava mosaic disease and associated whitefly vectors in South West and North Central Nigeria: Data exploration. Data in Brief, 19, 370-392. https://doi.org/10.1016/J.DIB.2018.05.016. 